\title{
Professional competencies in primary health care for attending to older adults
}

\author{
COMPETÊNCIAS PROFISSIONAIS PARA O ATENDIMENTO DE IDOSOS EM ATENÇÃO \\ PRIMÁRIA À SAÚDE
}

COMPETENCIAS PROFESIONALES PARA LAATENCIÓN DE ANCIANOS EN ATENCIÓN PRIMARIA A LA SALUD

Regina Rigatto Witt ${ }^{1}$, Maclaine de Oliveira Roos ${ }^{2}$, Nilson Maestri Carvalho ${ }^{3}$, Andria Machado da Silva ${ }^{4}$, Carla Daiane Silva Rodrigues ${ }^{4}$, Mariana Timmers dos Santos ${ }^{5}$

\begin{abstract}
Objective: to identify and analyze the necessary competencies in primary health care for attending to older adults. Methods: An exploratory, descriptive, and quali-quantitative study was developed. Three rounds of the Delphi Technique were conducted with participants from primary health care services and a multidisciplinary committee. The first questionnaire asked participants to indicate the competencies needed for attending to older adults in primary health care. They were compiled into a list and added to a Likert Scale (from 1 to 5) for the second and third questionnaires. A consensus criterion of $70 \%$ was adopted. Results: Twenty eight competencies were reached by consensus and were classified into twelve domains. Conclusions: the competencies reflect Brazilian health care policy and constitute a reference for professional health practice and education when caring for the older adult in primary health care.
\end{abstract}

\section{DESCRIPTORS \\ Aged}

Primary Health Care

Professional competence

Geriatric nursing

Health of the elderly

\begin{abstract}
RESUMO
Objetivo: Identificar e analisar as competências profissionais necessárias para o atendimento de idosos em cuidados primários de saúde. Método: Estudo exploratório descritivo quali-quantitativo. Foi utilizada a Técnica Delphi em três rodadas, com a participação de profissionais da rede básica e um grupo multidisciplinar de especialistas. O primeiro questionário solicitou que os participantes indicassem competências necessárias para o atendimento de idosos em cuidados primários. Estas foram compiladas em uma lista, que adicionada de uma Escala de Likert (de 1 a 5) compôs o segundo e terceiro questionários. 0 critério de consenso adotado foi $70 \%$. Resultados: Vinte e oito competências alcançaram o consenso, tendo sido classificadas em 12 áreas de domínio. Conclusão: As competências refletem as políticas brasileiras de saúde e constituem uma referência para a prática e a formação dos profissionais de saúde para o atendimento do idoso na atenção primária à saúde.
\end{abstract}

\section{DESCRITORES \\ Idoso \\ Atenção Primária à Saúde \\ Competência profissional \\ Enfermagem geriátrica \\ Saúde do idoso}

\section{RESUMEN}

Objetivo: Identificar y analizar las competencias profesionales necesarias para la atención de ancianos en cuidados primarios de salud. Método: Estudio exploratorio descriptivo cuali-cuantitativo. Fue utilizada la Técnica Delphi en tres rondas, con la participación de profesionales de la red básica y un grupo multidisciplinario de expertos. El primer cuestionario solicitó que los participantes indicasen competencias necesarias para la atención de ancianos en cuidados primarios. Estas fueron compiladas en un listado que, añadido de una Escala de Likert (de 1 a 5), compuso el segundo y tercer cuestionarios. El criterio de consenso adoptado fue el $70 \%$. Resultados: Veintiocho competencias alcanzaron el consenso, habiéndose clasificado en 12 áreas de dominio. Conclusión: Las competencias reflejan las políticas brasileñas de salud y constituyen una referencia para la práctica y la formación de los profesionales de salud para la atención al añoso en la atención primaria a la salud.

\section{DESCRIPTORES \\ Anciano \\ Atención Primaria de Salud \\ Competência profesional \\ Enfermería geriátrica \\ Salud del anciano}

\footnotetext{
${ }^{1}$ PhD, Public Health Nursing, Nursing School, , Universidade Federal do Rio Grande do Sul, Porto Alegre, RS, Brazil. ${ }^{2}$ Physician, City Health Secretariat, Porto Alegre, RS, Brazil. ${ }^{3}$ Master's in Administration, Universidade Federal do Rio Grande do Sul, Porto Alegre, RS, Brazil. ${ }^{4}$ Master's in Nursing, Universidade Federal do Rio Grande do Sul, Porto Alegre, RS, Brazil. ${ }^{5}$ Graduate Nurse at Universidade Federal do Rio Grande do Sul, Porto Alegre, RS, Brazil. 


\section{INTRODUCTION}

The growth in the number of older adults represents a concern for health care services all over the world. In Brazil, it is projected that by $2050,25 \%$ of the Brazilian population will be of older adults. According to the 2009 Census from the Brazilian Institute of Statistics, 9.9\% were older than 60 years of age ${ }^{(1)}$. Aging of the population is occurring more rapidly in emerging countries than in developed countries and occurs in the context of significant poverty ${ }^{(2)}$.

In the case of Brazil, approximately $70 \%$ of older persons depend on the Brazilian Public Health System for health assistance ${ }^{(3)}$. In this context, municipalities are responsible for providing primary health care for their residents, with administrative and financial support from the federal and state governments ${ }^{(4)}$.

The role of public health policies is to provide comprehensive health care, intersecting actions, quality health care, empowering older adults with more social control and continuous education for health care professionals. The Brazilian Senior Statute ${ }^{(5)}$ stands for their rights, including access to health care services. A National Health Policy for Seniors Citizens ${ }^{(6)}$ was developed to recuperate, maintain and promote their autonomy and independence, directing individual and collective measures for this purpose, and so that the qualification of management and care networks are reinforced by the Health Pact ${ }^{(7)}$.

Considering local characteristics, there are specific actions related to public health policies which should be put into practice respecting gender and age differences, such as education level, living arrangements, health habits, and preservation/improvement of functional capacity of older adults. The participation of the older adult in their community should also be taken into account. Another perspective that also needs to be considered at the local level is primary health care ( $\mathrm{PHC}$ ) teams' qualifications and undergraduate students training for effective care of older adult care, respecting their values, culture, and education.

Research conducted in the south of Brazil didn't find association between quality of life of older adults and the use of public primary health $\operatorname{care}^{(8)}$. This result indicates that because the Brazilian health model focuses on disease treatment, health professionals follow the same model. Therefore, they are not prepared to deal with older adults, their specific needs, or to work with an emphasis on prevention. This reality affects the quality of the care that older adults receive and their quality of life.

The World Health Organization has projects which aim to sensitize and educate primary health care $(\mathrm{PHC})$ providers on the specific needs of their older clients, considering that all clinical staff in $\mathrm{PHC}$ should receive training in core competencies for older adult care ${ }^{(9)}$. In accordance with this proposal, a concept of competence by the Pan American Health Organization was adopted for the development of this study; defined as the basic knowledge, abilities and attitudes needed for public health practice which means to solve community health problems in an effective and efficient way ${ }^{(10)}$.

The submission of the research proposal was part of a wider initiative named 'Healthy aging in the south of Brazil: addressing challenges and developing opportunities for health professionals and older people' The objective of this research was to develop a professional competence referential for the primary health care practice with older adults.

\section{METHOD}

An exploratory, descriptive, quali-quantitative study was carried out using the Delphi Technique, which is a structured research tool that allows a group of specialists to reach a consensus of opinions relating to a complex problem. The procedure for its application include the circulation of interactive questionnaires repeated times within a group of experts ${ }^{(11)}$.

Sample extraction considered experience and knowledge in the area of study, as recommended by the Delphi Technique. Selection criteria were a minimum of one year of practice in primary health care and undergraduate education.

Three groups of experts were established. Thirty health care professionals of a Health Centre in the city of Porto Alegre participated in the first round. After that, the development of the competence structure followed the International Council of Nurses proposal ${ }^{(12)}$ with the creation of a multiprofessional committee. Nurses $(n=14)$, physicians $(n=5)$, and social workers $(n=3)$, with master's $(n=12)$ or doctoral degrees $(n=10)$ accepted to take part in the committee. Most of them were from faculties of the University of Passo Fundo and the Federal University of Rio Grande do Sul.

The structure resulting from these phases was submitted to health care professionals of the Northwest and Islands Health Districts of Porto Alegre. Of the invited professionals, 47 ultimately enrolled in the third round: 17 physicians, 13 nurses, 8 dentists, 4 nutritionists, 2 pharmacists, 1 psychologist and 1 social worker. These professionals had master's $(n=10)$ or doctoral degrees $(n=1)$. They had been employed in their current position for less than 10 years $(n=18)$ and 30 were specialists, most of them in public health.

The Delphi Technique was conducted in three rounds, the first from October to December 2010, the second from March to April 2011, and the third from May to June 2011.

Round 1. The aim of the first questionnaire was to generate a list of competencies. To inform respondents, the adopted concept of competence was presented. They 
were then asked to list three competencies they thought necessary for attending to older adults' health in primary health care and justify each indication.

Round 2. Answers were compiled into a list of competencies, which comprised the second questionnaire. At this stage, a Likert scale with scores ranging from 1 (totally disagree) to 5 (totally agree) was added. The multiprofessional committee was invited to answer this questionnaire, to indicate their agreement or disagreement with the items on the list, to make comments on them and indicate other competencies they considered relevant.

Round 3. The questionnaire contained the competencies for which a consensus was reached during the second round of Delphi and new competencies indicated by experts. During this round, the level of agreement of the multiprofessional committee with the competencies listed was included in the questionnaire.

Collected data were submitted to statistical analysis in order to establish consensus among respondents. The level of agreement of answers was used for this purpose, as it is a reliable indicator of a consensus. A consensus criterion of a $70 \%$ response rate in the 4 (agree) to 5 (totally agree) for each competence was adopted.
For each competence statement, the following format criteria were followed: every competence title should be consistent with a verb, a noun, and could include one or more qualifiers ${ }^{(13)}$. Competencies were classified into twelve domains, following the statements of The American Association of Colleges of Nursing (AACN) $)^{(14)}$.

The project received approval (number 2007819) from the Ethics Committee of Research of the Federal University of Rio Grande do Sul. Written Informed Consent was obtained from all subjects. Each of the respondents was sent a separate questionnaire to collect professional and educational data. A code was used to identify questionnaires in order to assure the anonymity of participants.

\section{RESULTS}

The first round resulted into 48 competencies that were kept, mixed, or excluded after being submitted to the expert panel. As suggested by the group of experts, 4 competencies were added for the third round to the remaining 37. Of these 41 competencies, 28 reached consensus and were classified into twelve of the thirteen domains of the AACN document as follows:

Table 1 - Professional competencies for the primary health care of older adults by domain area and percentage of agreement - Porto Alegre, 2011.

\begin{tabular}{|c|c|c|}
\hline DOMAIN & COMPETENCIES & $\%$ \\
\hline \multirow{2}{*}{ Critical Thinking } & Demonstrates interest for the older adult and availability to deal with issues related to this life stage & 85 \\
\hline & Assesses issues related to their social and relational environment & 85 \\
\hline \multirow{4}{*}{ Communication } & Demonstrates disposition and patience to listen to the older adult & 87 \\
\hline & Demonstrates tolerance with the communication and natural difficulties of this life stage & 93 \\
\hline & Acts as a resource, listening to the older adult to attend his/her affective needs & 80 \\
\hline & $\begin{array}{l}\text { Establishes effective, compassionate and respectful dialog with the older adult, promoting the expression of their } \\
\text { needs }\end{array}$ & 96 \\
\hline \multirow{4}{*}{ Assessment } & Addresses difficulties of the life stage identifying alterations presented by the older adult & 91 \\
\hline & Recognizes and manages manifestations of psychological suffering, including psychosomatic ones & 75 \\
\hline & Assess older adults problems with objectivity, aiming at organizing priorities & 79 \\
\hline & $\begin{array}{l}\text { Acknowledges physical, psychological and social dimensions of ageing, differentiating normal aging processes } \\
\text { from illness and disease }\end{array}$ & 83 \\
\hline Technical Skills & $\begin{array}{l}\text { Demonstrates technical capacity in oneself professional area to attend physical, cognitive, psychological, spiritual } \\
\text { and social needs of the older adult }\end{array}$ & 80 \\
\hline \multirow{5}{*}{$\begin{array}{l}\text { Health Promotion, } \\
\text { Risk Reduction, and } \\
\text { Disease Prevention }\end{array}$} & Works respecting the principle of integrality, seeing the older adult in his/her totality and in a contextualized way & 89 \\
\hline & Establishes connections with the older adult, searching for ways to promote changes to improve their life quality & 82 \\
\hline & Identifies risk factors to the health of the older adult & 85 \\
\hline & Develops preventive actions, promoting the autonomy of the older person, aimed at improving their life quality & 72 \\
\hline & Is capable of identifying the frail older adult, including those submitted to situations of mistreatment and violence & 74 \\
\hline $\begin{array}{l}\text { Illness and Disease } \\
\text { Management }\end{array}$ & Correlates facts, signs and symptoms identified by the older adult for safe care planning and delivery & 80 \\
\hline $\begin{array}{l}\text { Information and Health } \\
\text { Care Technologies }\end{array}$ & Educates and helps older adults when referring them to other services, procedures or medication purchase & 86 \\
\hline \multirow{2}{*}{ Ethics } & Demonstrates an ethical attitude and responsibility in daily practice & 100 \\
\hline & Works with commitment and dedication to the older adults to attend their care needs & 83 \\
\hline \multirow{2}{*}{$\begin{array}{l}\text { Health Care Systems } \\
\text { and Policy }\end{array}$} & Seeks proactivity, promoting streamlined/efficient service & 85 \\
\hline & $\begin{array}{l}\text { Promotes embracement as a way of establishing priority for the attention and connection of the older adult with } \\
\text { the health service }\end{array}$ & 86 \\
\hline
\end{tabular}


...Continuation

\begin{tabular}{lll}
\hline DOMAIN & COMPETENCIES & $\mathbf{\%}$ \\
\hline Provider of Care & Recognizes the benefits of interdisciplinary team practice in care of older adults & 94 \\
\hline $\begin{array}{l}\text { Designer/Manager/Co- } \\
\text { ordinator of Care }\end{array}$ & Establishes priorities along with the older adult and family, facilitating their participation in the caring process & 76 \\
\hline & $\begin{array}{l}\text { Acts with autonomy in oneself professional area showing resolute ability to attend to the older adult and his/her } \\
\text { family }\end{array}$ & 79 \\
$\begin{array}{l}\text { Member of a Profes- } \\
\text { sion }\end{array}$ & $\begin{array}{l}\text { Demonstrates confidence in the proposed practice, promoting a caring relationship with the older adults and } \\
\text { Takes responsibility for long life learning required to care for older adults considering age related changes }\end{array} \quad 70$ \\
\hline
\end{tabular}

\section{DISCUSSION}

Health professionals consistently use critical thinking as a foundation of their public health practice. Indeed, they combine critical thinking and creative problem solving with assessment, planning, intervention, and evaluation processes to achieve health results/outcomes (14). When caring for older adults, they should consider societal attitudes toward the aging and how myths/prejudice held toward them influence the health care that older adults receive ${ }^{(14,15)}$. For this reason it is important that a competent multiprofessional health team 'demonstrate interest for the older adult and availability to deal with issues related to this life stage,' and also 'assess issues related to their social and relational environment.'

For public health professionals, effective communication is important to promote interpersonal relationships with the community and the health team. Communication between health professionals and patients can have farreaching implications for the physical and mental health of elderly patients. Effective physician-patient communication involves the exchange of both biomedical and psychosocial information, as well as the emotional and affective care that is so important to senior patient's health. The development of a trusting therapeutic relationship can be central to the health care of elderly patients ${ }^{(16)}$. According to this understanding, competencies focus on professionals' disposition, patience, tolerance, and compassionate and respectful dialog to attend to the affective needs of older adults.

Assessment of the predominant health problems of older people include chronic and acute situations and are exacerbated by the normal changes of aging and the increased risk of illness associated with old age ${ }^{(14)}$. It means that health professionals should 'address the difficulties of the life stage and identify alterations presented by the older adult.

Since treating such a large number of problems simultaneously seems unlikely, it may be necessary to prioritize the treatment. Therefore, it is crucial that health professionals and patients determine which health problems to select as health care priorities. The perspectives of both parties will contribute to a shared decision-making process of priority setting to achieve a mutually-agreed treatment plan ${ }^{(17)}$. However, to the competence 'assess older adults problems with objectivity, aiming at organizing priorities', low agreement on health and treatment priorities between patients and physicians has been observed, necessitating better communication between the two parties to strengthen mutual understanding.

Common health problems of older adults include mental disorders, which affects about two thirds of their population $^{(18)}$. Considering this situation, participants indicated the competence recognizes and manages psychological suffering, including psychosomatic manifestations.'

Technical skills competencies encompass correct procedures with respect to established rules, the need of manual skills and the use of adequate material in each situation. For attending to older adults in primary health care, health professionals indicated the competence 'demonstrate technical capacity in oneself professional area to attend to the physical, cognitive, psychological, spiritual and social needs of the older adult.

Just as the nurse's implementation of protective and preventive health measures and health promotion initiatives with individuals, families, and community were considered pivotal in primary health care ${ }^{(19)}$, the health care team also plays an important role when caring for older adults. From an integral view, they attempt to create links with them, identifying risks and developing preventive measures to guarantee their quality life.

For illness and disease management, instruments and guidelines to prevent and manage syndromes common to the older adults helps health professionals 'correlate facts, signs and symptoms identified by the older adult for safe care planning and delivery'. Besides this, participants considered health professionals should maintain updated knowledge about pharmacological treatment for common health problems of this life stage.

Health professionals should use communication tools in primary health care, to guarantee the quality of public health care. For older adults, instruments and guidelines to prevent and recognize communication impairments and technologies to facilitate adherence to treatment should be used ${ }^{(20)}$. These competencies for older adults are necessary considering their sensory and movement changes that have a high potential to 
impair communication. Health professionals should use techniques to overcome or minimize these communication barriers and to assist in understanding the meaning behind their behavior ${ }^{(14)}$.

For the older adults, many factors can be related to not adhering to treatment, highlighted by: higher consumption and prolonged use, collateral effects, symptom disappearance, medication ignorance, high costs and lack of motivation, illiteracy and memory problems. In this study, 'educates and helps older adults when referring them to other services, procedures or medication purchase' was considered the competence which would have the potential to address those needs.

Much emphasis was placed on the domain of ethics, which was a competence that obtained a hundred percent agreement. Professional values were also evaluated in a study in the south of Brazil, which investigated nurses' competencies in primary health care. Due to the number of competencies for which consensus was reached shows that health professionals are concerned with this area ${ }^{(19)}$.

Demonstrates tenderness and empathy to the older adults, trying to consider their feelings' was a competence considered essential when dealing with human diversity, as values and attitudes of frail older people and of the people who provide their care impact the way care is delivered, and the satisfaction of both patient and provider with that care ${ }^{(14)}$.

Public health professionals are expected to demonstrate an understanding of national health and social care policies ${ }^{(12)}$ and the effects of an aging society on this system. For this purpose, participants of this study indicated competencies that address older adults' needs for streamlined services and linkage with health services.

The use of interdisciplinary teams in care of older adults is necessary to face the complex issues that are related to their health and illness processes. These perspectives reached consensus in a study on nurses' competencies in primary health care in the south of Brazi|(19). Working as a team assumes professionals can apply knowledge of effective inter-professional working practices, establish and maintain constructive working relationships with other colleagues, contribute to effective multidisciplinary teamwork by maintaining collaborative relationships, and value the roles and skills of all members of the health and social care teams ${ }^{(12)}$.

\section{REFERENCES}

1. Instituto Brasileiro de Geografia e Estatística. Indicadores sociodemográficos e de saúde no Brasil 2009. Rio de Janeiro; 2009.

2. United Nations. Department of Economic and Social Affairs, Population Division. World population aging: 2013. New York; 2013.
As the designer, manager and coordinator of care, the health professional establishes priorities along with the older adult and family, facilitating their participation in the caring processes. These assessments and education strategies allow for maximizing older adults and family participation in health promotion, disease prevention, and illness management.

As a member of a profession, the competence expected from health professionals should allow for quality preventive and end-of-life care for older adults as essential, desirable, and integral components of practice ${ }^{(14)}$. In a previous study about primary health care nursing practice in the same setting, autonomy and life-long learning were also considered important competencies ${ }^{(19)}$.

\section{CONCLUSION}

Competencies were identified based on consensus, to be performed by health professionals in attending to older adults in primary health care. The built competencies fulfil criteria established by WHO, showing comprehensiveness to be applied internationally or nationally; at the same time, specific enough to provide support for decision making and fundamental and relevant for practice.

Their contribution to WHO's "age-friendly" primary health care project is of relevance, since it aims to sensitize and educate PHC providers about the specific needs of their older clients, with their application in at least one of the major areas; improving the attitudes, education and training of health care providers so that they can assess and treat conditions that afflict older persons and empower them to remain healthy.

Limitations of this study consist of the impossibility to collect online data in the first and third rounds of the Delphi Technique, with consequent difficulty to get feedback from some experts.

Although created in the Brazilian reality, the competencies constitute a referential for health professional practice and education elsewhere, allowing for the improvement of health care providers' attitudes, education and training. In Brazil, they can contribute to include the aging process as part of the life course and in all of its aspects as a priority for the Brazilian population, and to be included in undergraduate programs of health professionals.

3. Lebrão ML, Laurenti R. Saúde, bem-estar e envelhecimento: o estudo SABE no Município de São Paulo. Rev Bras Epidemiol. 2005;8(2):127-41.
Professional competencies in primary health care for attending to older adults Witt RR, Roos MO, Carvalho NM, Silva AM, Rodrigues CDS, Santos MT 
4. Pilger C, Menon MU, Mathias TAF. Health services use among elderly people living in the community. Rev Esc Enferm USP. 2013;47(1):213-20.

5. Brasil. Lei n. 10.741, de 10 de outubro de 2003. Dispõe sobre o estatuto do idoso e dá outras providências [Internet]. Brasília; 2003 [citado 2014 maio 12]. Disponível em: http://www. planalto.gov.br/ccivil_03/Leis/2003/L10.741.htm

6. Brasil. Ministério da Saúde. Portaria n. 2528, de 19 de outubro de 2006. Dispõe sobre a Política Nacional de Saúde da Pessoa Idosa [Internet]. Brasília; 2006 [citado 2014 maio 12]. Disponível em: http://dtr2001.saude.gov.br/sas/PORTARIAS/ Port2006/GM/GM-2528.htm

7. Brasil. Ministério da Saúde. Resolução n. 5, de 19 de junho de 2013. Dispõe sobre as regras do processo de pactuação de Diretrizes, Objetivos, Metas e Indicadores para os anos de 20132015 , com vistas ao fortalecimento do planejamento do Sistema Único de Saúde (SUS) e a implementação do Contrato Organizativo da Ação Pública da Saúde (COAP) [Internet]. Brasília; 2013 [citado 2014 maio 12]. Disponível em: http://bvsms.saude.gov. br/bvs/saudelegis/cit/2013/res0005_19_06_2013.html

8. Paskulin LMG, Vianna L, Molzahn A. Factors associated with quality of life of Brazilian older adults. Int Nurs Rev. 2009;56(1):109-15.

9. World Health Organization. Towards age-friendly primary health care. Geneva: WHO; 2004.

10. Suárez Conejero J, Godue C, García Gutiérrez JF, Suárez Conejero J, Godue C, García Gutiérrez JFS, et al. Competencias esenciales de salud pública: un marco regional para las Américas. Rev Panam Salud Pública. 2013;2013;34(1):47-53.

11. Keeney S, Hasson F, McKenna H. The Delphi technique in nursing and health research. Chichester: Wiley-Blackwell; 2011.
12. International Council of Nurses. ICN framework of competencies for the generalist nurse. Geneva: ICN; 2003.

13. World Health Organization. Competence in nursing. Geneva: WHO; 2003.

14. American Association of Colleges of Nursing. Recommended baccalaureate competencies and curricular guidelines for the nursing care of older adults. Washington: AACN; 2010.

15. Ferreira V, Ruiz T. Atitudes e conhecimentos de agentes comunitários de saúde e suas relações com idosos. Rev Saúde Pública [Internet]. 2012 [citado 2014 mar. 24];46(5):843-9. Disponível em: http://www.scielo.br/pdf/rsp/v46n5/11.pdf

16. Williams S, Haskard K, Di Matteo M. The therapeutic effects of the physician-older patient relationship: effective communication with vulnerable older patients. Clin Interv Aging. 2007;2(3):453-67.

17. Voigt I, Wrede J, Diederichs-Egidi H, Dierks ML, Junius-Walker U. Priority setting in general practice: Health priorities of older patients differ from treatment priorities of their physicians. Croat Med J. 2010;51(6):483-92.

18. Clemente AS, Loyola FAI, Firmo JOA. Concepções sobre transtornos mentais e seu tratamento entre idosos atendidos em um serviço público de saúde mental. Cad Saúde Pública. 2011;27(3):555-64.

19. Witt RR, Almeida MC. Identification of nurses'competencies in primary health care through a Delphi study in southern Brazil. Public Health Nurs. 2008;25(4):336-43.

20. Cintra FA, Guariento MEA, Miyasaki LA. Adesão medicamentosa em idosos em seguimento ambulatorial. Ciênc Saúde Coletiva. 2010;15 Supl. 3:3507-15. 